\title{
"One man one job": the marriage ban and the employment of women teachers in Irish primary schools
}

\author{
Jennifer Redmond ${ }^{\mathrm{a} *}$ and Judith Harford ${ }^{\mathrm{b}}$ \\ ${ }^{a}$ Department of History, National University of Ireland, Maynooth, Republic of Ireland; \\ ${ }^{b}$ School of Education \& Lifelong Learning, University College Dublin, Dublin, Republic of \\ Ireland
}

(Received March 2009; final version received 11 December 2009)

\begin{abstract}
In 1932, the Irish government, facing an economic downturn, introduced a marriage ban which required that female primary school teachers were required to resign on marriage. This followed a series of restrictive legislative measures adopted by Irish governments throughout the 1920s which sought to limit women's participation in public life and the public sector. Such a requirement emerged in several countries in response to high unemployment and applied principally to women's white-collar occupations, leading some commentators to argue that it stemmed from a social consensus rather than an economic rationale. Despite opposition to the ban from the Irish National Teachers' Organisation (INTO) on the basis that it was unconstitutional, would lead to fewer marriages and that married women were in fact more suited to teaching children, it remained in place until 1958. Although the ban is much referred to as part of the gender ideology that informed legislation in the early years of independent Ireland, the particular history of married women teachers has been little researched in the academic context. Over 50 years since the rescinding of the ban, this article examines its impact through an analysis of primary sources, including government cabinet minutes and the public commentary of the INTO and positions this history within the international context.
\end{abstract}

Keywords: marriage ban; teaching; primary schools; women

\section{Introduction}

A marriage ban, which obliged female primary school teachers to resign on marriage, was introduced in Ireland in 1932, coming into effect from 1933. The ban was one of a series of legislative measures introduced throughout the 1930 s which sought to limit the participation of women in the public sphere and safeguard their role in the home as wives and mothers. The marriage ban was in keeping with the gender ideology espoused in independent Ireland, whose social conservatism was the outcome of a powerful alliance between the state and the Catholic Church. For women at this time, the most valued roles were those of wife and mother or nun, dominant discourses of Irish womanhood idealising piety, devotion and selflessness. ${ }^{1}$ The ban remained in place until 1958, a period which reflected the peak of Catholic hegemony when Church and state policy were most closely aligned. As Fahey notes:

\footnotetext{
*Corresponding author. Email: Jennifer.Redmond@nuim.ie

${ }^{1}$ Tom Inglis, Truth, Power and Lies: Irish Society and the Case of the Kerry Babies (Dublin: University College Dublin Press, 2003).
} 
from the 1920s to the 1950s, the church's role in national self-definition, in law and the constitution, in social policy, education, health care, and in many other areas grew to the extent that, in some areas (such as schooling), the church was the institutional system to an exceptional degree. ${ }^{2}$

Church control over education in particular was absolute, the Catholic Church claiming not only a primary role for itself but a superior right in relation to the state. ${ }^{3}$ An example of this power was the Catholic Church's control over primary schooling. Although schools were in the main state-aided at primary level, they were denominational in terms of their management structures and teaching staff, the vast majority being Catholic. ${ }^{4}$

\section{Theorising women's relationship with teaching}

Building on the pioneering work of scholars such as Jackie Blount and Claudia Goldin in the United States, Alison Prentice in Canada, Alison Oram in the United Kingdom and Marjorie Theobald and Kay Whitehead in Australia, this paper adds to the growing corpus of scholarship theorising the economic and social structures which have governed women's work in teaching. Specifically, it examines the impact of the marriage ban on primary school teachers in the Republic of Ireland in the period 1932-1958, a topic that has thus far failed to be fully interrogated by scholars in the Irish context. ${ }^{5}$

Historically, women's relationship with teaching has been a complex one. Teaching was one of the first occupations considered respectable for middle-class women, viewed in many ways as an extension of the nurturing role. Much of the rhetoric surrounding women's admission to education in the nineteenth century emphasised the idealised and romanticised role which women would play as teachers. ${ }^{6}$ At various intervals single women teachers were valued over married and vice versa. The discourse surrounding the premium placed on single versus married women teachers testifies to the way in which women's marital status has been historically viewed as central to their identity as teachers. It also reflects the tension between the "image of true womanhood" and women's position as paid members of the labour force. ${ }^{7}$

Women teachers, both married and single, were at various stages discriminated against as a backlash against the power base they were achieving in the profession. Long dominated by males, teaching shifted towards becoming a feminised profession in the mid 1800s. Initially predominated by single, educated women keen to gain from

\footnotetext{
${ }^{2}$ Tony Fahey, "Growth and Decline of Churchly Religion," Studies: An Irish Quarterly Review 83, no. 332 (Winter, 1994): 372.

${ }^{3}$ Denis O'Sullivan, "Cultural Exclusion and Educational Change: Education, Church and Religion in the Irish Republic," Compare 21, no. 1 (1996).

${ }^{4}$ Tom O'Donoghue, The Catholic Church and the Secondary School Curriculum in Ireland, 1922-62 (New York: Peter Lang, 1999).

${ }^{5}$ The exception to this assertion is Eoin O'Leary, “The Irish National Teachers' Organisation and the Marriage Bar for Women National Teachers, 1933-1958," Saothar 12 (1985): 47-52; and Elayne Ruttledge entitled "From Miss to Missus: The Marriage Ban on Female National Teachers 1934-1958" (master's thesis, St. Patrick's College, DCU, 2005).

${ }^{6}$ Alison Prentice and Marjorie Theobald (eds.), Women who Taught: Perspectives on the History of Women and Teaching (Toronto, Buffalo, London: University of Toronto Press, 1991), 6; Judith Harford, The Opening of University Education to Women in Ireland (Dublin and Portland, OR: Irish Academic Press, 2008).

${ }^{7}$ Prentice and Theobald, Women who Taught, 13.
} 
the entry of women into higher education and the public sphere of professional paid work, these women soon became the focus of intense public scrutiny. Feminist educational historian Jackie Blount has noted that in the United States, concerns were voiced from the 1920s about the moral dilemma resulting from female gender role transgressions in the public sphere. As Blount notes:

teaching, long the exclusive province of males, shifted dramatically in the mid-1800s to become primarily female-identified work. In a further twist, many of these women teachers largely refrained from marriage, sometimes from conventional heterosexuality altogether, thus challenging not only prevailing notions of gender, but of sexuality as well. ${ }^{8}$

Kay Whitehead suggests that the backlash manifested itself in "psychological discourses" which:

were deployed to stigmatise single teachers. From the 1920s mature single women were increasingly portrayed as embittered, sexually deviant and threatening, and by the $1950 \mathrm{~s}$ compulsory heterosexuality and motherhood within marriage were seen to be the norm for all women. ${ }^{9}$

Similarly, married women teachers have, as a direct result of their marital status, been discriminated against, principally through marriage bans which, according to economic historian Claudia Goldin "provide the most numerically important form of all prohibitions in their impact on the employment of married women". ${ }^{10}$ Oram argues that as a form of direct discrimination through government policy, marriage bans were strongly influenced by ideological assumptions about women's rightful place in society as well as by an economic rationale. ${ }^{11}$ They also promoted an important social and moral agenda, whereby a married woman's domestic responsibilities were seen as her primary responsibilities. ${ }^{12}$ As Oram notes, "the marriage ban exemplified the assumption that families should be composed of a male breadwinner with dependent wife and children". 13 Such claims for the appropriateness of the family wage - as opposed to a double income model - were also seen in Ireland, informing the debate not just about teachers, but about women in many occupational sectors. Furthermore, in the British context, Cohn notes that the ban terminated the employment of older women, who, because of issues of tenure, were increasingly expensive, and allowed firms to employ younger, inexperienced and cheaper workers. ${ }^{14}$ This was an argument also used in the

\footnotetext{
${ }^{8}$ Jackie Blount, "Spinsters, Bachelors, and Other Gender Transgressors in School Employment, 1850-1990," Review of Educational Research 70, no. 1 (2000): 83.

${ }^{9}$ Kay Whitehead, "Postwar Headteachers' Perspectives of 'good' Teachers," Journal of Educational Administration and History 35, no. 1 (2003): 23-35.

${ }^{10}$ Claudia Goldin, Understanding the Gender Gap: An Economic History of American Women (New York: Oxford University Press, 1990), 160.

${ }^{11}$ Alison Oram, "Master Should Not Serve Under a Mistress: Women and Men Teachers, 19001970," in Teachers, Gender and Careers, ed. Sandra Acker (New York, London: Falmer, 1989), 21-34. See also Alison Oram, "Serving Two Masters? The Introduction of a Marriage Ban in Teaching in the 1920s," in The Sexual Dynamics of History: Men's Power, Women's Resistance, ed. London Feminist History Group (London: Pluto Press, 1983), 134-48.

${ }^{12}$ Alison Oram, Women Teachers and Feminist Politics, 1900-39 (Manchester and New York: Manchester University Press, 1996), 61.

${ }^{13}$ Ibid., 63.

${ }^{14}$ Samuel Cohn, Process of Occupational Sex-Typing: The Feminization of Clerical Labor in Great Britain, 1870-1936 (Philadelphia: Temple University Press, 1985).
} 
Irish context whereby single women who were paid less than their male counterparts could be used as a flexible labour supply. ${ }^{15}$ Sexual stereotypes and gendered occupational structures have thus shaped the experiences of women teachers internationally throughout the twentieth century. ${ }^{16}$

\section{The status of women in Irish society in the 1930s}

The marriage ban for women teachers cannot be understood without contextualisation. Much has been written on the gendered nature of the legislation adopted during the early years of the Irish Free State. ${ }^{17}$ The promise and potential of Irish independence did not provide the opportunities for women that many expected. ${ }^{18}$ The restrictions on women's roles in the public sphere have led many historians to argue that the period saw the development of a gendered ideology that placed women firmly within the home sphere through an alliance between the state and the Catholic Church. ${ }^{19}$ Whyte has argued that this alliance was natural given that most of the government ministers were Catholic, as was the majority of the population, and hence the implementation of Catholic ideology was only to be expected. ${ }^{20}$ According to Dunn, Irish society under the Free State government was "deeply rooted in a complex and apparently inseparable mixture of nationalism and Catholicism". 21 The established values and ethos of the Catholic Church were thus placed at the centre of the nascent political system. The merging of a Catholic with a national identity had a deep and lasting impact on Irish society and was especially restrictive of the role and freedom of women. The lack of economic opportunities for women in Ireland also directly

\footnotetext{
${ }^{15}$ Anna Bryson particularly refers to this practice in her study of Thekla Beere and the civil service, also pointing out that pay scales were deliberately determined so that single women would not reach the maximum on the scale before retirement. Thekla Beere (1901-1991) graduated in law from Trinity College, Dublin and also studied in the United States. She joined the civil service and rose to the rank of secretary of the Department of Transport and Power in 1959, the first woman to become head of a civil service department in Ireland since independence. She was a founder member of the youth movement, An Óige. Taoiseach Jack Lynch appointed her to chair the Commission on the Status of Women in 1970 and the "Beere Report" of the Commission in 1972 was an important milestone in the struggle for women's rights in Ireland. Source: Scoilnet: Portal for Irish Education, "Biographies", Department of Education and Science, http://www.scoilnet.ie/womeninhistory/content/unit4/biog.html, (accessed February 28, 2009). See also Anna Bryson, No Coward Soul: A Biography of Thekla Beere (Dublin: Institute of Public Administration, 2009), 56.

${ }^{16}$ Prentice and Theobald, Women who Taught, 3.

${ }^{17}$ The Irish Free State, or An Sáorstat, is the name adopted directly after the country was divided legislatively into two independent areas and refers to the 26 counties only. The 1937 constitution designated Ireland as Eire, with the Republic of Ireland being used after 1948. This article will relate only to the 26 counties of the Republic of Ireland. The six counties in Northern Ireland followed the legislation of the UK Parliament and thus rules on married women teachers were not the same in both jurisdictions.

${ }^{18}$ See Maryann Valiulis, "'Free Women in a Free Nation': Nationalist Feminist Expectations for Independence," in The Creation of the Dáil, ed. B. Farrell (Belfast: Blackwater Press, 1994),75-90.

${ }^{19}$ See, for example, Maryann Valiulis, "Power, Gender and Identity in the Irish Free State," Journal of Women's History 6, no. 4, 7, no. 1 (1995): 117-36.

${ }^{20}$ For a fuller discussion of this point see J.H. Whyte, Church and State in Modern Ireland, 1923-1979 (Dublin: Gill and Macmillan, 1980).

${ }^{21}$ Sean Dunn "Education, Religion and Cultural Change in the Republic of Ireland," in Christianity and Educational Provision in International Perspective, ed. W. Tulasiewicz and C. Brock (London and New York: Routledge), 89.
} 
contributed to their high rates of emigration as young single women to the UK and elsewhere. ${ }^{22}$ Familial ideology was evidenced in the 1937 Constitution which roused significant ire in the feminist groups of the time, particularly Article 40 which recognised the "family as the natural and primary fundamental unit group of Society" as well as highlighting a special position for women:

In particular, the State recognises that by her life within the home, woman gives to the State a support without which the common good cannot be achieved.

The State shall, therefore, endeavour to ensure that mothers shall not be obliged by economic necessity to engage in labour to the neglect of their duties in the home. ${ }^{23}$

The gender restrictions imposed by the state throughout the 1920s and 1930s covered such areas as women's right to participate on juries, their right to take examinations to gain entry to certain positions in the civil service and finally the ban on married women occupying jobs in the public sector. Furthermore, in practice women, even if single, tended not to gain access to the higher levels of management in the civil service, the notable exception being Thekla Beere who became the first woman to become a department secretary in 1959.

The marriage ban in the civil service came into effect much earlier than that in the teaching sector. Through a regulation instituted by the Minister for Finance, Ernest Blythe in 1924, it was decreed that "Female Civil Servants holding established posts will be required on marriage to resign from the Civil Service". ${ }^{44}$ The subsequent Civil Service Amendment Act (1926) banned women from taking exams for certain civil service positions, thereby instituting limits on women's career ambitions in the Irish public sector. In addition to a marriage ban, restrictive trade union practices and gender-differentiated pay characterised state policy on women in the labour market during this period. ${ }^{25}$ Indeed, apart from the Irish National Teachers' Organisation (INTO) no union, not even the Irish Women Workers' Union (IWWU), was sympathetic to the plight of female teachers when the marriage ban was proposed. Indeed, the president of the IWWU, Louie Bennett, referred to married women workers as a "menace to family life in so far as it has blocked the employment of men" in her address to the Irish Congress of Trade Unions in $1932 .{ }^{26}$ The timing of this speech means that it is unlikely Bennett was unaware of the impending ban for teachers. The lack of sympathy is most likely due to the fact that as a privileged and educated elite, women teachers' claims held little interest for those struggling for basic rights such as holiday pay and safe working conditions.

${ }^{22}$ For more on the issue of emigration see Jennifer Redmond, "Sinful Singleness? Discourses on Irish Women's Emigration to England, 1922-1948," Women's History Review 17, no. 3 (2008): 455-76.

${ }^{23}$ Article 40.2, 1937 Irish Constitution, also known as Bunreacht na hEireann. Note that the Constitutional clause remains unchanged to this day.

${ }^{24}$ Section 9 of the Civil Service Regulation Act (1924) on 26 April 1924 (Unnumbered Statutory Rules and Orders). For a detailed discussion of the submission by female civil servants objecting to the marriage ban and unequal pay to the Commission of Inquiry into the Civil Service, see Rosemary Cullen Owens, A Social History of Women in Ireland (Dublin: Gill \& Macmillan, 2005), 241-43. Cullen Owens also points out that Ireland was not unique in passing legislation limiting the number married women in employment, see p. 265.

${ }^{25}$ Eileen Connolly, "Durability and Change in State Gender Systems: Ireland in the 1950s," European Journal of Women's Studies 10 (2003): 65-86.

${ }^{26}$ As noted in Ruttledge, "From Miss to Missus," 14. 
Women's employment in Ireland: a brief statistical overview

Before examining why the marriage bar was extended from the civil service to the teaching profession in Ireland, it is necessary to first contextualise the employment of women teachers within the wider national female labour market. When the ban was being considered, women teachers comprised a majority in their field (although not at principalship level): in 1930 there were 9298 women primary school teachers and just 4324 men. $^{27}$ Excluding teaching religious of both sexes, there were a total of 7727 women and 4058 men teaching at primary level. The figures at secondary level were less contrasting where, for the same period, there were a total of 1194 male and 1357 female teachers employed. ${ }^{28}$ Women teachers were categorised within labour force statistics under the "professions" category, the vast majority working as either teachers or nurses. Only a minority of women worked as doctors or lawyers. When looking specifically at teaching, women teachers only constituted $9 \%$ of the total female labour force in 1926, thus they were not a significant cohort in the labour force as a whole. $^{29}$ In addition to the minority status of women teachers within the overall female labour force, few married women were classified as working at this time. As Ruttledge has observed, although the vast majority of women in the workforce in Ireland were single (77\%) with just $6.9 \%$ of married women registered as working, women teachers stood out as having unusually high rates of marriage with $27 \%$ of them reported as such in $1926 .{ }^{30}$

Furthermore, it must be noted that women's overall participation in the workforce throughout this time period was relatively low. In 1926, men registered as at work outnumbered women by a $2.7: 1$ ratio; ${ }^{31}$ in 1936 , this ratio remained at just less than $2.7: 1,32$ by 1946 the ratio had risen to $2.8: 1 .{ }^{33}$ Undoubtedly the official statistics do not capture women who engaged in casual employment for which they did not pay taxes, for example, in the domestic service area. Thus it is evident from the data that the small numbers of women involved in teaching meant that they could hardly expect to rally large sections of the female labour force in protest, and while they could undoubtedly have caused widespread disruption in the education sector by striking, it seems that this option was not considered. The marriage gratuity may have mitigated the blow for many female teachers, a clause of the marriage ban regulation that will be discussed in the next section.

\footnotetext{
${ }^{27}$ Figures taken from INTO Archives, Department of Education Annual Report 1929-30, Appendix II, 118. Note that although there were twice as many women as men at primary school level, men were far more likely to be principals with a total of $2883 \mathrm{men}$ in this role as compared to just 2132 women. Note that the figures for teachers includes assistant teachers and junior assistant mistresses (women only) who were teaching in schools.

${ }^{28}$ Figures taken from INTO Archives, Department of Education Annual Report 1929-30, Appendix II, 151.

${ }^{29}$ Central Statistics Office, Table 1, Department of Industry and Commerce, Census of Population Report, 1926. Stationery Office: Dublin, 1928.

${ }^{30}$ Ruttledge, "From Miss to Missus," 6.

${ }^{31}$ Calculation made from Table 1, Department of Industry and Commerce, Census of Population Report, 1926. Stationery Office: Dublin, 1928.

${ }^{32}$ Ibid.

${ }^{33}$ Ibid.
} 
Why was a marriage ban introduced in teaching?: deconstructing the mindset of the Free State educational policy agenda

The educational priorities of the new Free State government were at best conservative. Taking the view that schooling under British rule had been a mechanism of cultural assimilation, nationalist leaders saw the education system as a key agent in the promotion of a nationalist consciousness. The movement for curricular reform, a movement inspired by the ideology of cultural nationalism, drove educational policy following independence and effectively shaped the course of educational policy up until the 1960 s. ${ }^{34}$ Reflecting the heavy emphasis on cultural nationalism which was to shape educational policy in the early decades of independence, Pádraig Ó Brolcháin, the new chief executive officer for education in the Cumann na nGaedheal ("Association of Irish People") government, outlined the new direction for education policy in 1922 as follows:

In the administration of Irish education, it is the intention of the new government to work with all its might for the strengthening of the national fibre by giving the language, history, music and tradition of Ireland, their natural place in the life of Irish schools. ${ }^{35}$

Although difficult economic and social circumstances would have impeded the adoption of education as a priority for administrative reform, the social conservatism of the body politic and of the churches at the time would also have contributed to this overall approach. ${ }^{36}$ In the context of a conservative and rather insular educational machinery and a society steeped in conservative and traditionalist notions of the role and function of woman, the introduction of a marriage ban in teaching met with widespread government and church approval.

After being raised as an issue intermittently since 1929, on 22 March 1932 a proposition by the Minister for Education, John M. Sullivan, to the Executive Council seeking them "to consider the question of introducing a new rule providing for the retirement of women national teachers on marriage" was passed. ${ }^{37}$ It is likely that primary school teachers were targeted for the ban because primary school education was compulsory and state funded, whereas secondary education at this time was feepaying and thus teachers in this sector were not considered public servants in the state in the same way as primary teachers. The government sought the opinions of the bishops, who after seven months delay, responded by saying they would offer no opinion on the matter, paving the way for the ban to be introduced. It is likely that should the hierarchy have rejected the ban, it would not have been implemented given their powerful hold over the government at the time and their involvement in the running of primary schools throughout Ireland. However, given the Church's position regarding the role of women in Irish society at this time, this response was not unexpected.

\footnotetext{
${ }^{34}$ John Coolahan, Irish Education: Its History and Structure (Dublin: Institute of Public Administration); Tom O'Donoghue, Bilingual Education in Pre-independent Irish-speaking Ireland, 1800-1922: a History (Lewiston, NY; Lampeter and Wales: E. Mellen Press, 2006); Judith Harford, "Ireland," in Teacher Education in the English-Speaking World: Past, Present and Future, ed. Tom O'Donoghue and Clive Whitehead (Charlotte, NC: Information Age Publishing), 75-92.

${ }^{35}$ INTO (Irish National Teachers' Organisation), Irish School Weekly, February 11, 1922, 127. Available from the INTO Archives.

${ }^{36}$ Coolahan, Irish Education, 45.

${ }^{37}$ Cabinet Minutes, NA DT/s 6231A. John M. Sullivan was a member of Cumann na nGaedheal (later Fine Gael) and a university professor. He served as Minister for Education from 1927 until the government's defeat by Fianna Fail in 1932.
} 
The marriage ban also offered the potential for a greater number of teaching positions to be held by religious, and while this was not an argument explicitly stated by the hierarchy for its lack of opposition, it is interesting to speculate if it was indeed an influential factor. Given the fact that there were greater numbers of female religious than male, coupled with the practice of women (lay and religious) predominantly teaching at primary school level, it is a point worth considering. Indeed, Ruttledge goes further when she asserts that female religious had the most to gain from the marriage bar and that "experienced lay teachers were frequently dismissed to create jobs for novices and [that] the religious held sway over senior posts". 38

Not surprisingly, however, the decision to introduce a marriage ban was met with condemnation by the primary teachers' union, INTO ${ }^{39}$ Following confirmation of the government's stance, T.J. O'Connell, General Secretary of the INTO, requested a formal meeting with the Minister for Education. ${ }^{40}$ A detailed memorandum, outlining the government's position on the issue, was then forwarded to members of the INTO Executive Council. Among the reasons stated for the government's support of a marriage ban were the "upset" caused to schools following the absence of a pregnant married teacher; the economic circumstances which did not favour double income families; and the problems associated with "married teachers in mixed schools". 41

The government's assumption was clearly that married women teachers would automatically become mothers, again illustrating the national ideology at this time which equated women with motherhood and marriage. It was also assumed that women teachers would find the task of combining work and motherhood too taxing and would hence be absent from work for additional periods on top of their confinement. Married women teachers were of course not the only women who were facing the combined burden of work and family responsibilities: thousands of working-class mothers had always assumed this dual role without any public commentary or legislation from the government to ease their burden.

In November 1932 the Fianna Fáil ("Warriors of Destiny") government, which had come to power after the general election of that year, discussed the ban at a meeting of its Executive Council. In a document detailing the meeting, the objections of the INTO are outlined. These included: difficulties in getting the best type of woman candidate for teaching positions if the restrictions were brought in; the fact that the ban may cause some women to view teaching as merely a stepping stone to marriage and thus not take the responsibilities of the role seriously; the age at which this may affect

\footnotetext{
${ }^{38}$ Ruttledge, "From Miss to Missus," 11.

${ }^{39}$ The INTO was the union for primary school teachers only and did not allow religious to join, thus represented the interests of lay teachers who were predominantly employed in Catholic-run institutions. INTO membership rates for the period are difficult to calculate due to the lack of extant statistical records. However, it is possible to give membership rates for selected years which show high rates of membership amongst employed teachers. For example, in 1930 when there were a total of 7727 women and 4058 men teaching at primary level there were 7520 female and 4226 male members of the INTO (excluding student members who are not differentiated by gender and could explain the discrepancy in the male figures). Figures for membership calculated from table "Summary of Membership for 1830" in INTO, Annual Directory and Year Book for 1931 (Dublin: INTO, 1931), 75.

${ }^{40}$ T.J. O'Connell to Minister for Education, March 14, 1932, National Archives, Dublin. In addition to being general secretary of the INTO, O'Connell was also leader of the Labour Party during this period.

${ }^{41}$ Acting assistant secretary to the Executive Council, March 16, 1932, National Archives, Dublin. Note that women taught boys and girls at primary school level.
} 
women coincided with the time they would have experience of teaching and be at their best, thus constituting a loss to the profession and a waste of training; married women teachers had sympathy with children and had shown themselves to be excellent as many had won prizes; absences from work by married women could be adequately covered by having a full panel of substitute teachers; and, finally, that married women teachers could afford to pay for help in the home, thus their home life would not suffer. ${ }^{42}$

In response to the INTO's objections, the government outlined a number of counter arguments to support their position. A central element of the government's argument rested on the resource implications for replacing married women teachers on maternity leave. ${ }^{43}$ Although the government admitted that a loss would be incurred in the first years of the ban, it was argued that the replacement of married women with new teachers who would be at the minimum scale of pay would compensate for this loss. Furthermore, the introduction of a marriage gratuity such as that which existed in the Civil Service could also be introduced, softening the blow somewhat. The marriage gratuity was granted to women teachers who had at least seven years' service and constituted one-twelfth of her average annual salary for the three years preceding her marriage, subject to a maximum of one year's salary. ${ }^{44}$ This gratuity would be provided to women leaving the profession in order to compensate them for their loss of employment and to help set up their new marital homes. The Department of Education asserted in a memorandum to the INTO that female teachers normally married at the age of 31 or 32 , thereby giving at least 10 years service before marriage. This appears to have been posited as a justification for the cost of training teachers who would then be forced to retire. ${ }^{45}$ However, the INTO refuted the assertion stating that no statistics had been produced by the Department to verify this claim, exposing it as a ploy in the guise of economic efficiency to justify the ban. ${ }^{46}$ The government's attitude towards women of marriageable age in the public sector was succinctly captured by a contemporary commentator, Mary S. Kettle, who famously commented that "women from their entry until they reach the ages of 45 or 50 are looked upon as if they were loitering with intent to commit a felony - the felony in this case being marriage". 47

Perhaps the real crux of the issue was the fact that married women teachers were often in double-income families, often married to fellow professionals and thus enjoying a higher standard of living than many other families. This is indicated in the following observation from the same memorandum:

There also arises the question of one man one job, ${ }^{48}$ particularly in view of the present economic state of the country, and the local irritation or jealousy which arises owing to the comparatively large combined incomes where the man and wife are both teachers, or where a woman teacher is married to a substantial farmer or shopkeeper. ${ }^{49}$

\footnotetext{
${ }^{42}$ Memorandum, "The Question of the Proposed New Rule Providing for the Discontinuance of Women Teachers on Marriage," November 15, 1932, NA DTs6231a, National Archives, Dublin.

${ }^{43}$ Ibid.

${ }^{44}$ Department of Education, Rules and Regulations for National Schools under the Department of Education (Dublin: Stationery Office, March 1934), 5.

${ }^{45}$ Ibid.

${ }^{46} \mathrm{O}$ 'Connell, History of the Irish National Teachers' Organisation, 282.

${ }^{47}$ As quoted in Bryson, No Coward Soul, 58.

${ }^{48}$ The phrase "one man one job" was used in a memorandum on the topic of employing married women teachers. See "Question of the Proposed New Rule."

${ }^{49}$ Ibid.
} 
The politics of appealing to an electorate who may be prone to jealousy of the middle-class families who enjoyed secure, professional, well-remunerated employment reveals much about the time. Women teachers appear in this instance merely to have been scapegoats for the government's inability to provide an adequate number of jobs. Married women teachers losing their jobs would not provide unskilled labourers with employment; a skewed logic was clearly in operation.

The latent issue of sex again raised its contentious head in the considerations on the marriage ban. Unlike their male counterparts, married women teachers could get pregnant, thus literally embodying sexual relations. As stated above, the same government memo also raised the issue of whether or not the employment "of married women teachers in mixed schools is desirable". 50 Out of 5400 primary schools in the country at the time, approximately 3300 , or nearly two-thirds, were mixed schools. ${ }^{51}$ However, the practice of women teaching both boys and girls was one that had a long history at this point, thus the conservatism displayed through this suggestion appears to be an attempt to justify the decision rather than a justifiable reason for introducing the ban. This attitude, however, persisted. As late as 1953, Seán Moylan, Minister of Education, noted: "There is bound to be comment and a degree of unhealthy curiosity in mixed schools of boys and girls and even in schools for girls only, during the later months of pregnancy of married women teachers". 52 Thus married women teachers were too visible a symbol of sexuality and reproduction and, in order not to raise unseemly questions, it was better to remove them from the classroom. This logic failed to address the questions children might raise about their own mothers' pregnancies.

\section{Operationalising the ban}

Following lengthy deliberations, the Department of Education announced in December 1932 its intention to introduce a marriage ban from 1 October 1933 on all women national school teachers who commenced service after that date, a concession achieved by the INTO. It did not, therefore, affect those who had qualified before this time. This allowed for a lengthy gap in the effect of the ban being felt as many teachers who were married and not affected could carry on teaching until their retirement. This is perhaps the reason why the ban lasted so long because the situation did not become critical until many of this cohort were due to retire in the 1950s. However, a culture of resignation on marriage appears to have developed, meaning that it became the norm that women would resign upon marriage. Although the marriage ban only applied to the primary school sector, it also had implications for the employment of secondary school teachers. Cullen Owens has highlighted the fact that the employment practices of schools at the time meant that, "in effect few schools employed married women". ${ }^{53}$ Furthermore, as Pat O'Connor has noted, although:

the marriage bar was not legally enforced in many other areas of paid employment (e.g. the banks), up to 1973 there was a clear expectation that women would retire on marriage

\footnotetext{
${ }^{50}$ Ibid.

${ }_{52}^{51}$ Ibid.

${ }^{52}$ Minister for Education, Memorandum for the Government, "The Rule Requiring Women Teachers to Retire on Marriage," February 14, 1953, NA DT/s6369a, National Archives, Dublin.

${ }^{53}$ Cullen Owens, Social History of Women, 246.
} 
and this was institutionalised through the marriage gratuity ... through separate and higher pay scales for married men, and through related tax and social welfare arrangements. ${ }^{54}$

Reluctantly, the INTO accepted the government's decision and the regulations concerning the employment of women teachers were changed. O'Leary has pointed to the critical fact that at this time the INTO did not have any women on its Central Executive Council (CEC). ${ }^{55}$ Although it cannot be assumed that having women on the CEC would have automatically meant a stronger or more successful fight against the ban, it is interesting to speculate what would have happened if a married woman teacher had been on the CEC at the time, particularly if she was also a mother. Would the government have been so confident in outlining their proposals had they been face to face with a married woman teacher? However, it is also important to point out that T.J. O'Connell was resolutely and very publicly against the ban. As Margaret Ó hÓgartaigh has highlighted, O'Connell's own wife was a teacher, thus he can be viewed as having a personal and authentic approach in his objections as illustrated in the following quotation taken from The Irish School Weekly. ${ }^{56}$ Referring to the justification of the ban due to the current poor economic conditions, O'Connell commented:

The 'economic circumstances of the present time' are, let us hope, of a relatively temporary character and should not be allowed to weigh very much, if at all, in deciding to make a change which will be permanent in its operation, and which even if made now could not affect the general economic position except to an inappreciable extent for the next dozen years. ${ }^{57}$

This vociferous opposition, however, went unheeded by the government. In December 1932 the fundamental injustice of the ban was again clearly articulated by O'Connell:

A man, just because he is a man, may get married and continue in his profession. A woman, just because she is a woman, must in the same circumstances relinquish her post, no matter how highly qualified she may be or how brilliant her record as a teacher. ${ }^{58}$

O'Connell also criticised the Catholic Church and the Catholic Managers' Association's support for the ban, questioning how it was consistent with teachings on the importance of marriage given that the ban could deter many young women from marrying. ${ }^{59}$ However, the only concession the INTO managed to negotiate was that current members were exempt from the rule, hence those married women already in employment could not lose their jobs. At this point, it must also be noted that the

\footnotetext{
${ }^{54}$ Pat O'Connor, Emerging Voices: Women in Contemporary Irish Society (Dublin: Institute of Public Administration, 1999), 38. Ruttledge also supports this thesis, citing the Department of Education's acknowledgement of the practice in a 1953 memorandum on the subject of the marriage bar. See Ruttledge, "From Miss to Missus," 20.

${ }^{55}$ See O'Leary, "The Irish National Teachers' Organisation."

${ }^{56}$ Margaret O hÓgartaigh, "Female Teachers and Professional Trade Unions in Early Twentieth-Century Ireland," Saothar 29 (2004): 33-41.

${ }^{57}$ T.J. O'Connell, "Married Women's Rule," Irish School Weekly, November 19, 1932, 1236.

${ }^{58}$ T.J. O'Connell, "Employment of Married Women Teachers," Irish School Weekly, December 3, 1932, 1287.

${ }^{59}$ Ibid.
} 
INTO was simultaneously fighting proposed cuts in teachers' pay, and thus the marriage ban, while objected to, tended to be overshadowed by the bigger issue of a reduction in wages. As Ruttledge observes, the two issues did not hold equal positions on the agenda of the INTO: "The INTO's Congress in 1934 was completely dominated by the revised salary scales. A resolution was passed unanimously for the withdrawal of the ban, but no discussion whatsoever took place". 60

As the ban was implemented through a change in the regulations for teachers as adopted by the Department of Education, there was no legislative process through which the ban could have been debated in either House of the Oireachtas (Irish Parliament), Dáil Éireann (the House of Representatives) or Seanad Éireann (the Senate). This meant that the government avoided having to justify its position through lengthy debates. It also meant that politicians across the political spectrum did not have to face the prospect of justifying their support for the ban, although it was obvious that it had wide support as it had been considered by two successive governments comprised of each of the two dominant political parties respectively. As the INTO noted:

However fiercely Ministers and ex-Ministers may gird at one another in public from time to time, there would not appear to be the smallest shade of difference between them when they come to settling their respective attitudes towards the demands of the teachers. ${ }^{61}$

In addition to the ban there were two other areas in which women in the teaching profession were treated unequally: pay and retirement. Married men teachers were paid more than all women and all single male teachers, a rule that was to last until 1977, when Ireland's participation in the European Community forced an end to such inequalities in the labour market. Compulsory early retirement was enforced for women teachers in primary schools in 1938 reducing the age of retirement from 65 to 60 years old. This had implications for pay and pension entitlements and was to last until 1948 when it was eventually rescinded. ${ }^{62}$ The implications of pension differentials continue, however, to be felt today. ${ }^{63}$

The ban, once introduced, proved short-sighted and ill-considered. A lack of forward planning on the part of the government meant that when a shortage of primary school teachers emerged in the 1940s, the government had to modify the existing rule prohibiting the full-time employment of married women teachers at primary school level. In 1944 married women teachers were allowed to fill temporary roles in schools where a school manager was unable to find a suitable alternative teacher. ${ }^{64}$ This was strictly limited to three months for Catholic women teachers. However, longer periods were permitted for qualified Protestant married women teachers because of their

\footnotetext{
${ }^{60}$ Ruttledge, "From Miss to Missus," 30.

${ }^{61}$ INTO, Irish School Weekly, December 10, 1932, 1325.

62“"As Time Goes By - A Brief View of INTO History," INTO, http://www.into.ie/text/ROI/ TheINTO/History/ (accessed February 3, 2009).

${ }^{63}$ For a detailed account of the pension implications of primary school teachers in Ireland, including women affected by the ban, see Michael Moroney, National Teachers' Salaries and Pensions, 1831-2000 (Dublin: Institute of Public Administration).

${ }^{64}$ Goldin asserts that this was also the case in the United States. See Claudia Goldin, "Marriage Bars: Discrimination against Married Women Workers from the 1920s to the 1950s," 514, in Patrice Higgonet, David S. Landes and Henry Rosovsky (eds.), Favorites of Fortune: Technology, Growth, and Economic Development Since the Industrial Revolution (Cambridge, MA: Harvard University Press, 1991), 511-36.
} 
greater shortage and the fact that schooling was strictly sectarian during this period. ${ }^{65}$ Amid calls to rescind the marriage ban as one way of addressing the shortage of primary school teachers, the Minister for Education, Seán Moylan, issued a memorandum reaffirming the government's commitment to upholding it:

the care and direction of a home, and the rearing of a family, constitute the whole-time assignment sufficient to tax the strength and energy of the normal woman. The addition of another arduous avocation, involving extended daily absences from the home, must impose a physical and mental strain on the woman herself, and she could not be expected to reach a high standard of efficiency in both spheres of activity. ${ }^{66}$

Clearly the Minister's memorandum on the issue was only addressing the exigencies of the life of a middle-class woman as many others had to endure longer and more arduous work in the unskilled sector. The memorandum also alluded to the desirability that a man be the sole provider for his family; that many teachers married "men of substance"; and that the constitution, with its fundamental emphasis on family, was in itself supportive of the ideology of the ban. The Minister rejected arguments that the ban would deter women from entering the profession or make them merely "mark time" in teaching before getting married. He also argued that any temporary relaxation of the rules should be avoided since it would make it impossible to reinforce it subsequently, indicating his own lack of awareness of the unpopularity of the rule and of his position as a result. A supporting memorandum was prepared by the Minister for Finance, Seán MacEntee, who argued that the modification of the ban to deal with the immediate shortage of primary school teachers was the most judicious route to follow. ${ }^{67}$ This position was no doubt influenced by the fact that birth rate statistics indicated that the current demand for primary schooling would ease by 1956 .

\section{Rescinding the ban}

The government's eventual decision to rescind the ban appears to have been motivated not out of any desire to promote fairness or equality but out of a concern that women were gravitating towards professions other than teaching. In a memorandum on the possible rescinding of the ban, the government expressed its concern that:

the maintenance of the Rule may be affected in practice if the employment of married women in other callings, such as medicine and commerce, continues to increase, as the position may be reached where young women would choose a career in fields offering

\footnotetext{
${ }^{65}$ Schooling in Ireland has traditionally been organised along denominational lines at primary, secondary, university and teacher education levels. See Judith Harford, "The Emergence of a National Policy on Teacher Education in Ireland," Journal of Educational Administration and History 41, no. 3 (2009): 45-56; Judith Harford, "An Experiment in the Development of Social Networks for Women: Women's Colleges in Ireland in the Nineteenth Century," Paedagogica Historica 43, no. 3 (2007): 365-82. It may be that, at local level, these strictures on temporary contracts were not observed, although there is no definitive evidence in this regard.

${ }^{66}$ Minister for Education, Memorandum for the Government, "The Rule Requiring Women Teachers."

${ }^{67}$ Minister for Finance, Memorandum for the Government, "Retirement of Women Teachers on Marriage," February 19, 1953, NA DT s6321b, National Archives, Dublin.
} 
continued employment after marriage and would be drawn away from entering on a career as teacher. ${ }^{68}$

It was also the case that by the time the ban was lifted, approximately one quarter of the teaching personnel in primary schools in Ireland were untrained, thereby raising the prospect of serious quality issues in Irish education. ${ }^{69}$ The extra places provided in teacher training colleges and the extension of the retirement age had failed to address the problem. It was also finally admitted that the point at which women were being forced to retire was directly at the point where they were "reaching the peak of their teaching efficiency". 70 Thus the utilisation of women as a flexible labour force to be called on in times of need can again be seen to be in operation.

At a cabinet meeting on 20 May 1958, it was agreed that the marriage ban on female national teachers should be abrogated with effect from 1 July $1958^{71}$ on the basis that teaching would not prevent a married woman from carrying out "her duties and obligations in regard to the creation and maintenance of a home". 72 The INTO General Secretary at the time, D. O'Céileachair, welcomed the lifting of the ban in a lengthy article of An Múinteoir Náisiúnta [The National Teacher]. The issue of women's loss of service and the marriage gratuity was raised as a significant issue: women who had accepted the marriage gratuity had the option to pay it back over time or to relinquish their claim to the inclusion of previous teaching in the calculation of their pension and retirement benefits. ${ }^{73}$ Furthermore, women in the profession before 1st July 1958 who wished to retire on marriage still had the option of receiving the marriage gratuity, a regulation perhaps continued for those women who did not need or wish to continue working after marriage. The gratuity, however, was denied to any woman who entered the profession after this date, thereby ending any incentive for women to leave the profession on marriage.

The decision to rescind the ban, however, was not universally welcomed. The Labour Party, the third largest political party in the State and essentially a social democratic party, cautioned that it set "a dangerous precedent that might spread to other women working in the State service". 74 The party had obviously ceased to be imbued with O'Connell's influence and was thus more interested in men's economic prospects than women's. The opposition party, Fine Gael, also expressed a negative opinion, with General Richard Mulcahy, T.D., a former Minister of Education, accusing the government of reversing its position without giving adequate reasons for such a decision. ${ }^{75}$

\footnotetext{
${ }^{68}$ Department of Education, Memorandum on the Retirement of Women Teachers on Marriage, February 19, 1953, National Archives, Dublin.

${ }^{69}$ INTO, "Removal of "the Ban," An Múinteoir Náisiúnta, (Dublin, May 1958), 3-9. Available from INTO Archives.

${ }^{70}$ Ibid., 5, quoting from the Minister for Education, Jack Lynch.

${ }^{71}$ Minute to the Private Secretary, Department of Education, from the Taoiseach's Office. NA DT/s6231C.

${ }^{72}$ Memorandum from the Department of Education to the Government, April 28, 1958, NA, DT, S6231C, cited in Connolly, "Durability and Change in State Gender Systems," 79.

73"'Removal of 'the Ban." The INTO advised that teachers would be better off to repay the gratuity in order to boost their pensions.

${ }^{74}$ The Sunday Review, September 20,1959, cited in Connolly, "Durability and Change in State Gender Systems," 79.

75"'Removal of "the Ban,"” 9. The INTO General Secretary severely criticised this view, arguing that when Mulcahy had been in office he had refused to give his reasons for not rescinding the ban when asked by the INTO.
} 
The need for "adequate" reasons, besides the inherent inequity and the lack of teachers, reveals the attitude that women should not be given such "privileges" lightly, if at all.

The decision to rescind the ban was warmly welcomed by the INTO, with General Secretary O'Céileachair stating that the "revoking of the "Ban" removes, I hope, for all time, a matter that has been agitating our minds ever since it was introduced. Teachers warmly welcome the Minister's action and time will prove him right". ${ }^{76}$ However, the INTO soon displayed its own gender bias. The very year the ban was rescinded, the union objected to the appointment of a woman as principal of a Protestant primary school on the basis that because of the small number of principalships in Protestant schools, this post should have been awarded to a man who would likely have had family responsibilities and not to a single woman. ${ }^{77}$ The earlier outright objection to any discrimination on the basis of sex by the INTO had clearly waned and when it came to competition between men and women for teaching posts, the idea that men were more deserving had not yet been eliminated.

\section{Conclusion}

This article, the first comprehensive investigation of the history of the marriage ban on primary school teachers in Ireland, has highlighted the particular social, economic and ideological context which shaped the personal and professional lives of women teachers during this period. From a feminist perspective, the ban promoted patriarchal gendered social practices which posited that the apposite place for middle-class women was the home. While its implementation mirrored that of other countries, the marriage ban in the teaching profession in Ireland differed in a number of ways. Firstly, it happened a decade later than in its nearest counterpart, the UK. Secondly, it happened at national level, rather than through local education authorities, because of the structure of administration in Ireland. Furthermore, the ban was brought in through a change to the Department of Education's regulations for teachers rather than through national legislation, thereby avoiding public debate. Unlike the UK, Ireland did not have laws such as the Sex Disqualification (Removal) Act (1919) under which objectors to the regulation would have been able to mobilise. ${ }^{78}$ In fact, the Irish state throughout the 1920s and 1930s adopted greater amounts of legislation that differentiated the societal position of men and women in public life. As late as 1971, contraception was illegal, divorce was prohibited under the constitution, and abortion still remains unavailable. Single mothers and separated women were ineligible for welfare payments, and women were overtly discriminated against in the areas of education, employment and the tax and welfare systems. ${ }^{79}$ In contrast to the situation in the UK, where women formed a substantial proportion of the labour force and where divorce and contraception were widely available and women had access to a wider range of social security and health facilities, in the Republic of Ireland, only one in fifteen

\footnotetext{
${ }^{76}$ Ibid.

${ }^{77}$ National Archives, DT S 6231C letter dated February 27, 1958 cited in Connolly, "Durability and Change in State Gender Systems," 80.

${ }^{78}$ Oram notes that this Act should have protected married women in Britain from being disqualified from teaching. However, in a number of court cases brought by married women teachers this law was completely disregarded (ibid., 136). The point being made here is that there was no similar law in Ireland through which objections could be made or protections sought.

${ }^{79}$ Jenny Beale, Women in Ireland: Voices of Change (Dublin: Gill and Macmillan, 1986), 3.
} 
married women worked outside of the home in the early $1970 \mathrm{~s} .{ }^{80}$ These statistics expose the legacy of the legislation adopted in the earlier period of independence and the economic policy pursued by various governments up to this point which privileged the development of men's employment to provide a family wage. Such policies became endemic in Irish society and spread to areas in the private sector through custom or normative practices rather than legislation. This was to continue until the inequalities in the Irish labour market were dismantled after entry into the European Union in 1973.

This article has sought to illuminate an important and under-researched facet of Irish women's history and a particularly significant issue in the history of their struggle to attain the full rights and privileges of citizenship ostensibly guaranteed in two constitutions. The importance of this history is not to be underestimated. A significant aspect of the historical narrative is the argument proffered concerning appropriate employment for women and the demands on their time due to both work and home responsibilities, issues which dominate contemporary discourses on gender. Indeed, the implications of the ban remain to this day where retired women teachers continue to be affected, namely through their diminished pension entitlements. ${ }^{81}$

\section{Acknowldegement}

The authors would like to acknowledge the kind assistance of Ann McConnell and Claire Garvey of the INTO archives for their invaluable help in sourcing primary sources and statistical information used in this article.

\section{Notes on contributors}

Jennifer Redmond is an experienced researcher and teacher, having worked in academic roles in Trinity College Dublin, University College Dublin and NUI Maynooth. She completed her doctoral dissertation in 2008 on the history of Irish women's emigration to England between 1922 and 1948. She also has an MPhil from Trinity College and a BA (Hons) from UCD. Her research is primarily on Irish emigration to Britain, the Irish diaspora and also topics in women's history. The topic of her current IRCHSS fellowship is Irish emigration during World War II, details are given below. She is currently preparing a monograph based on her thesis.

Judith Harford is director of teaching and learning and joint-director of the Post-Graduate Diploma in Education at the School of Education, University College Dublin. She has published internationally in the areas of gender and education, teacher education policy and history of education. She is a member of the Board of the Teacher Education Policy in Europe Network and a convenor of the Teacher Education Research Network of the European Educational Research Association (EERA). She is a peer reviewer for a number of international journals and is on the editorial advisory board of the New Hibernia Review. She is series editor for Peter Lang: Oxford ('Re-Thinking Education' Series) and a visiting research associate at the Faculty of Policy and Society, Institute of Education, University of London. External examining work includes The University of Western Australia and the University of Limerick, Ireland.

\footnotetext{
${ }^{80}$ Ibid., 5 .

${ }^{81}$ This article stems from a wider research project currently being undertaken by the authors which will include interviews with women affected by the ban, exploring the issue from a qualitative perspective.
} 